\title{
Quality of life and functional capacity during the treatment of hematologic neoplasms
}

\author{
Qualidade de vida e capacidade funcional durante \\ o tratamento de neoplasia hematológica
}

Calidad de vida y capacidad funcional durante el
tratamiento de neoplasia hematológica

Monique Vanderlinde de Souza, Marina Christofoletti, Anne Ribeiro Streb, Giovani Firpo Del Duca*

Universidade Federal de Santa Catarina (UFSC), Florianópolis, SC, Brazil

\begin{abstract}
Introduction: Cancer is a serious pathology with a high incidence and complex diagnoses. Emotional and environmental factors, the deleterious effects of these, and lifestyle affect different outcomes. Objective: Investigate the association between quality of life and functional capacity during treatment for hematologic cancer. Methods: A cross-sectional study with intentional sampling of patients of both sexes with hematologic neoplasms, interviewed in 2016. Quality of life (QF) was measured by the European Organization for Research and Treatment of Cancer Quality of Life Questionnaire. For the definition of functional capacity in basic and instrumental activities of daily life, the Katz Index and the Lawton Scale, respectively, were used. Data were analyzed by correlations and comparisons of means tests. Results: The 52 participants presented an average QF score of approximately 60.6. Among the functional scales, the worst result was in role functioning (46.8), while for symptoms, it was fatigue (48.1). The results of more expressive QF indicators were the strong correlation
\end{abstract}

* MVS: BS, e-mail: moniquevandl@hotmail.com

MC: MS, e-mail: marinachriss@outlook.com

ARS: Master's Student, e-mail: tina.anne@hotmail.com

GFDD: PhD, e-mail: gfdelduca@gmail.com

Fisioter Mov. 2018;31:e003137

Page 01 of 13 
between role functioning and fatigue $(r=-0.60)$, and a moderate correlation between social functioning and financial difficulties $(r=-0.45)$. There was still an association between role functioning and functional incapacity in daily activities $(p=0.017)$. Fatigue was associated with incapacity for basic activities $(p=0.018)$, while insomnia was correlated with instrumental activities $(\mathrm{p}=0.032)$. Conclusion: The association between lower QF scores and functional incapacity reflects the damaging effect of hematologic neoplasms on daily activities.

Keywords: Neoplasms. Functional Capacity. Life Style. Activities of Daily Living. Health Promotion.

\section{Resumo}

Introdução: O câncer é uma grave patologia de elevada incidência e complexidade de diagnósticos. Situações pessoais, ambientais, os efeitos deletérios destas e o estilo de vida modulam diferentes desfechos. Objetivo: Investigar a associação entre a qualidade de vida e a capacidade funcional durante o tratamento de câncer hematológico. Métodos: É um estudo transversal de amostragem intencional de pacientes de ambos os sexos com neoplasia hematológica, entrevistados em 2016. A qualidade de vida (QV) foi avaliada pelo European Organization for Research and Treatment of Cancer Quality of Life Questionnaire. Para a definição da capacidade funcional em atividades básicas e instrumentais da vida diária, foram empregados o Índice de Katz e a escala de Lawton, respectivamente. Os dados foram submetidos à análise de correlação e testes de comparação de médias. Resultados: Os 52 participantes apresentaram o escore médio de QV de 60,6. Nas escalas funcionais, o pior resultado foi o desempenho de papel (46,8), enquanto nos sintomas, foi a fadiga $(48,1)$. Os indicadores de QV com resultados mais expressivos foram as correlações entre o desempenho de papel e a fadiga $(r=-0,60)$ e entre a função social e dificuldades financeiras $(r=$ -0,45). Ainda houve associação entre a escala de desempenho de papel e a incapacidade funcional para atividades $d a$ vida diária $(p=0,017)$. A fadiga esteve associada à incapacidade para atividades básicas $(p=0,018)$, enquanto a insônia para as atividades instrumentais ( $p=0,032)$. Conclusão: $A$ associação entre menores escores de QV e a incapacidade funcional reflete os prejuízos da neoplasia hematológica para a realização de atividades diárias.

Palavras-chave: Neoplasias. Incapacidade Funcional. Estilo de Vida. Atividades Cotidianas.

Promoção da Saúde.

\section{Resumen}

Introducción: El cáncer es una grave patología de alta incidencia y complejidad de diagnósticos. Situaciones personales, ambientales, los efectos deletéreos de esta y el estilo de vida modulan diferentes resultados. Objetivo: Investigar la asociación entre calidad de vida y la capacidad funcional durante el tratamiento del cáncer hematológico. Métodos: Un estudio transversal de muestra intencional de pacientes con neoplasia hematológica de ambos sexos, entrevistados en 2016. La calidad de vida (CV) fue evaluada por la European Organization for Research and Treatment del Cancer Quality of Life Questionnaire. Para la definición de la capacidad funcional en actividades básicas e instrumentales de la vida diaria, fueron empleados el Índice de Katz y la escala de Lawton. Los datos fueron sometidos al análisis de correlación y pruebas de comparación de promedios. Resultados: Los 52 participantes presentaron la puntuación promedio de CV de 60,6. Entre las escalas funcionales, el peor resultado fue el desempeño de papel $(46,8)$, mientras que, en los síntomas, fue la fatiga $(48,1)$. Los indicadores de CV con resultados más expresivos fueron la correlación entre el desempeño de papel y la fatiga $(r=-0,60)$ y entre función social y las dificultades financieras $(r=-0,45)$. También hubo asociación entre la escala de desempeño de papel y incapacidad funcional para actividades de la vida diaria $(p=0,017)$. La fatiga ha estado asociada a la incapacidad para actividades básicas $(p=0,018)$ y el insomnio para las actividades instrumentales $(p=0,032)$. Conclusión: La asociación entre menores escores de CV y la incapacidad funcional refleja los perjuicios de la neoplasia hematológica.

Palabras clave: Neoplasias. Incapacidad Funcional. Estilo de Vida. Actividades Cotidianas. Promoción de la Salud. 


\section{Introduction}

In recent years, cancer has been considered a serious public health problem, because of the high incidence and complexity of subdivisions in diagnoses, in which changes in the outcome depend on the patient's environmental situation and the particular deleterious effects of the disease $[1,2]$. Data from the National Cancer Institute (INCA in the Portuguese acronym) [3] estimate that by 2025 , there will be more than 20 million new cases of the disease worldwide, with a higher incidence among developing countries. In Brazil, around 600 thousand new cases were expected for the biennium 2016-2017 [3]. The origin of the disease is the multiplication and uncontrolled growth of cells that have mutated their genetic material and, consequently, fail to respond to the organism's control mechanisms [4].

Considered a malignant neoplasm, cancer is subdivided into solid tumors and hematologic neoplasms [5]. Specifically, hematologic neoplasms present a smaller proportion of the diagnoses, approximately $6.6 \%$ worldwide, but are responsible for a relatively higher number of deaths, at around 7.1\% [6]. These include leukemia, lymphoma, and multiple myeloma [7], which are expressed by changes and dysfunctions in the blood cells, usually affecting the blood and blood-forming organs, and disseminating without respecting anatomical barriers [8] .

Because of intense catabolism [9], as well as other symptoms, such as pain and fatigue, individuals undergoing treatment become progressively prone to an inactive lifestyle. Consequently, there is a reduction in functional capacity, due to greater dependence in both activities of daily living (ADL), which are linked to self-care [10], and in instrumental activities of daily life (IADL), which are related to life in society. In addition to the deleterious implications of therapeutic procedures, such conditions may compromise the way that individuals with cancer perceive their quality of life $[11,12]$. The evaluation of quality of life in this population has been adopted since it allows monitoring of symptoms of the disease and of the treatment, as well as their physical and psychosocial effects, to indicate possible interventions to minimize and/or to address the difficulties these patients face [13].

In fact, cancer is one of the chronic diseases with the highest mortality in Brazil and in the world. Studies on quality of life that concern individuals with cancer are scarce and inconclusive, especially in the case of hematologic neoplasms [14]. Investigations in this area will enable the establishment of future interventions aimed at reducing, as far as possible, the difficulties caused by the disease and optimizing therapeutic procedures [13], including, for example, understanding patients' tolerance of the side effects of toxicity treatment. Thus, the present study aimed to investigate quality of life and its association with functional capacity in individuals with hematologic cancer undergoing hospital treatment.

\section{Methods}

This is a cross-sectional study with intentional sampling of individuals with hematologic cancer admitted to a reference hospital in Florianopolis, Santa Catarina. This hospital has accreditation for treatment of onco-hematologic diseases, with outpatient care and hospitalization at different periods and days. The therapeutic activities have a multidisciplinary team, with traditional and complementary medicine approaches. The target population comprised those diagnosed with hematologic cancer and undergoing oncological therapy. The sample was obtained for convenience, based on accessibility and links with the study site. The inclusion criteria were adults of both sexes, 18 years or older, who were inpatients or visiting the ambulatory clinic, undergoing oncological treatment, who were willing and interested in participating in the study, and who agreed to do so by signing the informed consent form. There were two exclusion criteria: patients in the terminal phase of the disease and those in a state of poor lucidity that did not allow responses to the interview.

Data were collected in October 2016, through an interview, with a mean duration of 10 minutes, by a trained interviewer. Quality of life was assessed through a translated and validated version of the European Organization for Research and Treatment of Cancer Quality of Life Questionnaire (EORTC-QLQ-C30) [15]. The variables investigated were global quality of life, assessed with four functional scales (cognitive, emotional, social, and role functioning), symptoms (fatigue, nausea and vomiting, pain, dyspnea, insomnia, loss of appetite, constipation, and diarrhea), and financial difficulties. All these items were individually transformed into a linear scale between 0 to 100 points. For general health and quality of life, and in the functional scales, a larger score (closer to 100) represents a better general state and a higher level of functionality, respectively. Finally, in the symptom scales and the financial difficulty item, a larger score represents worse symptomatology and side effects. 
For the definition of functional capacity in ADL and IADL, the Katz Index [16] and the Lawton Scale [17], respectively, were used. The first instrument assesses the autonomy of the individual in basic selfcare activities, such as bathing, dressing, going to the toilet, sitting and standing, feeding, and controlling the functions of urination and evacuation, while the second covers activities related to the ability to be independent in community life via eight questions, such as using the telephone, traveling via public transport, shopping, cooking, tidying up, washing clothes, taking care of money, and taking medicine. The dependence classifications for both basic and instrumental activities of daily living were independent, partially dependent, and totally dependent, respectively determined by the categorizations of 0,1 , and 2 or more activities with dependence.

Stata software version 13.0 was used to analyze the data. In the descriptive statistics, absolute (n) and relative (\%) frequencies, 95\% confidence intervals (95\% $\mathrm{CI})$, mean $(\mu)$, and standard deviation (SD) were used. In the inferential statistics, for continuous data, Pearson's correlations were performed for variables with normal distributions and Spearman's for those that contained at least one variable without data normality at the intersection, using the definition given by the ShapiroWilk test. The correlation coefficients were interpreted as negligible $(|\mathrm{r}|<0.20)$, weak $(|\mathrm{r}|<0.40)$, moderate $(|r|<0.60)$, strong $(|r|<0.80)$, and very strong $(|r|$ $>0.80$ ) [18]. For the comparison of means, the residue normality test was applied initially. In cases with a normal distribution, a one-way ANOVA was used, with differences between the means indicated by Tukey's Post Hoc and Duncan's tests. When normality was absent, the authors opted for a logarithmic transformation. When normality of data was achieved, ANOVA was used, while in cases of non-normality, the original data were analyzed with the Kruskal-Wallis test, with differences between the means indicated by the Mann-Whitney test. The level of significance was $5 \%$ for all tests. The present study was approved by the Human Ethics and Research Committee of the Federal University of Santa Catarina, under protocol number 1.769.275/2016.

\section{Results}

Fifty-two subjects participated in the study, with a mean age of $53.6 \pm 2.5$ years. Table 1 shows that most interviewees were female (55.8\%), with white skin color (88.5\%), $\geq 12$ years of education (51.9\%), and living with a partner (53.9\%). Regarding clinical characteristics, the most frequent diagnosis was of lymphoma (42.3\%), and intravenous chemotherapy was the most used therapeutic resource for treatment of the disease $(55.7 \%)$. The majority of patients reported having started treatment more than one year ago $(51.0 \%)$.

Table 1 - Sociodemographic and clinical characterization of individuals with hematologic neoplasms submitted to hospital treatment. Florianopolis, 2016

\begin{tabular}{|c|c|c|}
\hline \multicolumn{3}{|c|}{$\begin{array}{ll}\text { (to be continue } \\
\end{array}$} \\
\hline Variables & $\mathbf{N}$ & $\%$ \\
\hline \multicolumn{3}{|l|}{ Sex } \\
\hline Male & 23 & 44.2 \\
\hline Female & 29 & 55.8 \\
\hline \multicolumn{3}{|l|}{ Age (years) } \\
\hline 18 to 39 & 11 & 21.2 \\
\hline 40 to 59 & 20 & 38.5 \\
\hline$\geq 60$ & 21 & 40.3 \\
\hline \multicolumn{3}{|l|}{ Skin color } \\
\hline White & 46 & 88.5 \\
\hline Brown & 01 & 1.9 \\
\hline Black & 05 & 9.6 \\
\hline \multicolumn{3}{|l|}{ Marital status } \\
\hline With partner & 25 & 48.1 \\
\hline Without partner & 27 & 51.9 \\
\hline \multicolumn{3}{|l|}{ Schooling (years) } \\
\hline$\leq 8$ & 06 & 11.5 \\
\hline 8 to 11 & 18 & 34.6 \\
\hline$\geq 12$ & 28 & 53.9 \\
\hline \multicolumn{3}{|l|}{ Diagnostic } \\
\hline Leukemia & 19 & 36.5 \\
\hline Lymphoma & 22 & 42.3 \\
\hline Myeloma & 11 & 21.2 \\
\hline \multicolumn{3}{|l|}{ Treatment } \\
\hline Oral chemotherapy & 12 & 23.1 \\
\hline Intravenous chemotherapy & 29 & 55.7 \\
\hline $\begin{array}{l}\text { Transplantation of bone } \\
\text { marrow }\end{array}$ & 03 & 5.8 \\
\hline Others & 08 & 15.4 \\
\hline \multicolumn{3}{|l|}{ Begin treatment (months) } \\
\hline$<6$ & 17 & 34.7 \\
\hline 6 to 12 & 07 & 14.3 \\
\hline$>12$ & 25 & 51.0 \\
\hline
\end{tabular}




\begin{tabular}{lrr}
\hline & & (conclusion) \\
\hline Variables & N & \% \\
\hline Caregiver & & \\
$\quad$ Yes & 46 & 88.5 \\
$\quad$ No & 06 & 11.5 \\
Caregiver relationship & & \\
$\quad$ Partner & 20 & 38.5 \\
$\quad$ Children & 09 & 17.3 \\
Brother & 03 & 5.8 \\
Other & 14 & 26.9 \\
No & 06 & 11.5 \\
\hline
\end{tabular}

Source: authors themselves.

Table 2 presents the averages of the scales and quality of life items evaluated. Overall health status and overall quality of life had an average of $60.6 \pm 2.8$. Among the functional scales, the worst result was for paper performance $(\mu=46.8 \pm 5.4)$, followed by emotional function $(\mu=52.2 \pm 3.9)$, and social function $(\mu=62.5$ $\pm 4.7)$. For symptoms, the worst results were observed for fatigue $(\mu=48.1 \pm 4.5)$, financial difficulties $(\mu=39.1$ \pm 5.6 ), and insomnia $(\mu=36.5 \pm 5.7)$.

Table 2 - Mean and standard deviation of the global measure of health and quality of life, functional scales and symptoms of individuals with hematologic neoplasms submitted to hospital treatment. Florianopolis, 2016 (to be continued)

\begin{tabular}{lc}
\hline Variable & Mean \pm DP \\
\hline $\begin{array}{l}\text { Global health measure/Quality of life* } \\
\text { Functional scale* } \\
\quad \text { Role functioning }\end{array}$ & $60.6 \pm 0.8$ \\
\hline
\end{tabular}

\begin{tabular}{lc} 
& (conclusion) \\
\hline Variable & Mean \pm DP \\
\hline Emotional function & $52.2 \pm 3.9$ \\
Cognitive function & $67.6 \pm 4.4$ \\
Social function & $62.5 \pm 4.7$ \\
Symptoms** & \\
$\quad$ Fatigue & $48.1 \pm 4.5$ \\
Nausea and vomit & $16.4 \pm 2.9$ \\
Pain & $31.4 \pm 4.9$ \\
Symptoms items** & \\
$\quad$ Dyspnea & $16.0 \pm 4.2$ \\
Insomnia & $36.5 \pm 5.7$ \\
Loss of appetite & $21.8 \pm 4.7$ \\
Constipation & $34.0 \pm 5.8$ \\
\hline Diarrhea & $10.9 \pm 3.6$ \\
\hline Financial Item ${ }^{* *}$ & \\
Financial difficulties & $39.1 \pm 5.6$ \\
\hline
\end{tabular}

Source: authors themselves.

Note: * The closer to 100 , the better the overall quality of life; ** The closer to 100 , the worse the overall quality of life.

Figure 1 shows the description of ADL and IADL according to the degree of dependence of individuals with hematologic neoplasms undergoing hospital treatment. Among the ADL, the lowest proportion of independence was observed for dressing (21.1\%), bedding/lifting (15.4\%), and going to the bathroom (13.5\%). Regarding the IADL, the areas evaluated indicated less independence in performing laundry (48.1\%), cleaning the house (46.2\%), and traveling using some public transport (37.2\%).

Figure 1. Degree of dependence (\%) for the basic and instrumental forms of life in patients with hematologic neoplasms in cancer treatment. Florianopolis, 2016.

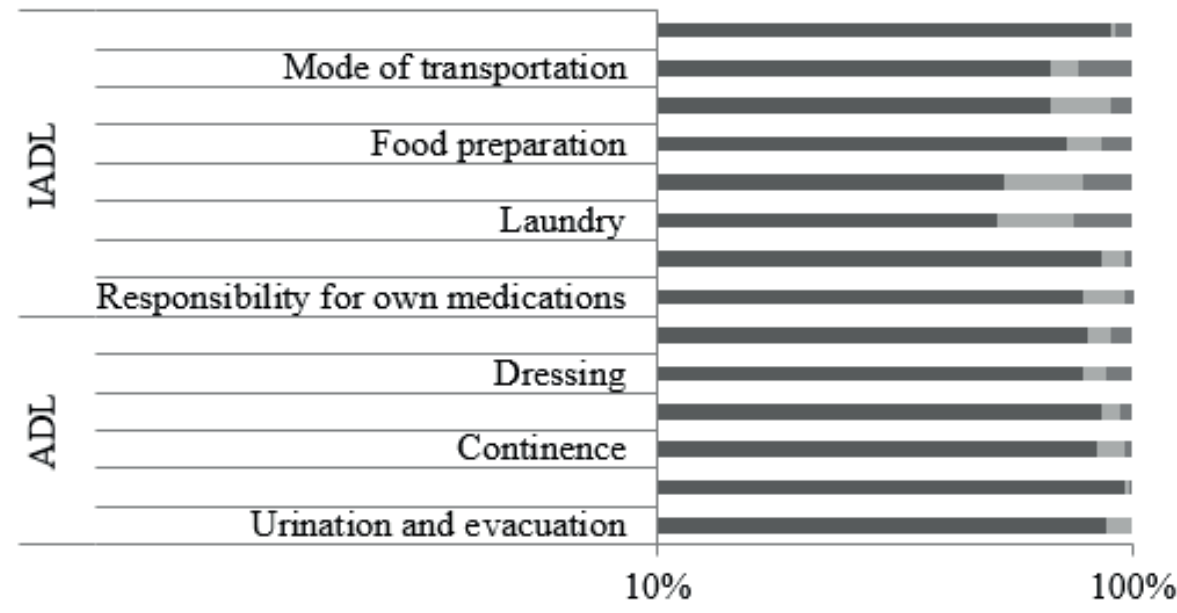

Independents

- Partially dependent 
In the analysis of correlations between function and symptom scores in individuals with hematologic neoplasms undergoing hospital treatment, it was found that general health and quality of life had moderate correlations with dyspnea symptoms $(|\mathrm{r}|=-0.5294)$ and insomnia ( $\mathrm{r}=-0.4023)$. However, the paper performance scale correlated strongly with fatigue $(|\mathrm{r}|=-0.6015)$, moderately with dyspnea $(|\mathrm{r}|=-0.4124)$, and weakly with loss of appetite ( $|r|=-0.3636)$. In relation to emotional function, symptoms of fatigue $(|r|=-0.4793)$, pain $(|r|=-0.4488)$, and insomnia ( $|\mathrm{r}|=-0.5082)$ correlated moderately. Finally, social function had a moderate correlation with the financial difficulties item $(|\mathrm{r}|=-0.4510)$. Further details of the correlations can be seen in Table 3.

Table 3 - Correlation between EORTC-QLQ-C30 instrument function and symptom scores in patients with hematologic neoplasms on cancer treatment. Florianópolis, 2016

\begin{tabular}{lccccccccc}
\hline & Fatigue & $\begin{array}{c}\text { Nausea } \\
\text { and } \\
\text { vomit }\end{array}$ & Pain & Dyspnea & Insomnia & $\begin{array}{c}\text { Loss of } \\
\text { appetite }\end{array}$ & Constipation & Diarrhea & $\begin{array}{c}\text { Financial } \\
\text { difficulties }\end{array}$ \\
\hline $\begin{array}{l}\text { Global health } \\
\text { measure/ } \\
\text { Quality of life }\end{array}$ & $-0.3882^{\star}$ & -0.1159 & -0.1933 & $-0.5294^{*}$ & $-0.4023^{*}$ & -0.0805 & 0.0199 & -0.2650 & -0.0706 \\
$\begin{array}{l}\text { Role } \\
\text { functioning }\end{array}$ & $-0.6015^{\star}$ & $-0.3252^{\star}$ & -0.2620 & $-0.4134 \dagger$ & $-0.2800^{\star}$ & $-0.3636 \dagger$ & 0.1688 & -0.2538 & -0.1042 \\
$\begin{array}{l}\text { Emotional function } \\
\text { Cognitive function }\end{array}$ & $-0.4793^{\star}$ & -0.1513 & $-0.4488+$ & $-0.3932 \dagger$ & $-0.5082^{*}$ & -0.0793 & -0.2550 & -0.2021 & -0.2569 \\
Social function & -0.1835 & -0.1230 & -0.0708 & -0.2281 & -0.1593 & 0.0295 & 0.0169 & 0.0003 & 0.0630 \\
\hline
\end{tabular}

Source: authors themselves.

Note: * $p$-value $\leq 0.05$, extracted from the Spearman test. $\dagger p$-value $\leq 0.05$, extracted from the Pearson test

Comparisons of quality of life indicators according to functional capacity for ADL and IADL in subjects with hematologic neoplasms undergoing hospital treatment are presented in Table 4. A negative association was found between the paper performance scale and functional disability for ADL $(p=0.017)$ and IADL $(p=0.030)$. As for symptoms, fatigue and pain were associated with inability in ADL, while insomnia was associated with inability to perform IADL.

Table 4 - Association of quality of life indicators with the functional capacity for basic and instrumental activities of daily living in individuals with hematological neoplasms submitted to hospital treatment. Florianopolis, 2016

(to be continued)

\begin{tabular}{|c|c|c|c|c|c|c|c|c|}
\hline \multirow[b]{3}{*}{ Variable } & \multicolumn{4}{|c|}{$\begin{array}{l}\text { Functional capacity for basics activities of daily } \\
\text { living }\end{array}$} & \multicolumn{4}{|c|}{$\begin{array}{l}\text { Functional capacity for instrumental activities } \\
\text { of daily living }\end{array}$} \\
\hline & None & 1 & $\geq 2$ & & None & 1 & $\geq 2$ & \\
\hline & $\begin{array}{l}\text { Means } \\
\pm D P\end{array}$ & $\begin{array}{l}\text { Means } \\
\pm D P\end{array}$ & $\begin{array}{l}\text { Means } \\
\pm D P\end{array}$ & $\mathrm{p}$ & $\begin{array}{l}\text { Means } \\
\pm \mathrm{DP}\end{array}$ & $\begin{array}{l}\text { Means } \\
\pm \mathrm{DP}\end{array}$ & $\begin{array}{l}\text { Means } \\
\pm \mathbf{P}\end{array}$ & p \\
\hline $\begin{array}{c}\text { Global health } \\
\text { measure/Quality } \\
\text { of life }\end{array}$ & $63.7 \pm 3.0$ & $58.3 \pm 7.5$ & $52.8 \pm 7.7$ & $0.375^{\mathrm{a}}$ & $66.1 \pm 4.0$ & $65.6 \pm 5.1$ & $56.7 \pm 4.2$ & $0.333^{\mathrm{a}}$ \\
\hline \multicolumn{9}{|l|}{ Functional scale } \\
\hline Performance & $54.9 \pm 6.8$ & $55.6 \pm 14.1$ & $19.4 \pm 7.9^{*} \dagger$ & $0.017^{a}$ & $60.7 \pm 8.8$ & $66.7 \pm 12.2$ & $35 \pm 7.2^{*} \dagger$ & $0.030^{a}$ \\
\hline Emotional function & $56.4 \pm 4.8$ & $61.1 \pm 10.0$ & $36.1 \pm 7.6$ & $0.101^{a}$ & $64.2 \pm 7.3$ & $56.3 \pm 8.6$ & $45.6 \pm 5.2$ & $0.113 a$ \\
\hline Cognitive functions & $72.1 \pm 5.4$ & $44.4 \pm 11.9$ & $66.7 \pm 8.9$ & $0.1679^{a}$ & $78.6 \pm 8.3$ & $62.5 \pm 13.9$ & $63.9 \pm 5.5$ & $0.222^{\mathrm{a}}$ \\
\hline
\end{tabular}




\begin{tabular}{|c|c|c|c|c|c|c|c|c|}
\hline \multirow[b]{3}{*}{ Variable } & \multicolumn{4}{|c|}{$\begin{array}{l}\text { Functional capacity for basics activities of daily } \\
\text { living }\end{array}$} & \multicolumn{4}{|c|}{$\begin{array}{c}\text { Functional capacity for instrumental activities } \\
\text { of daily living }\end{array}$} \\
\hline & None & 1 & $\geq 2$ & & None & 1 & $\geq 2$ & \\
\hline & $\begin{array}{l}\text { Means } \\
\pm \mathrm{DP}\end{array}$ & $\begin{array}{l}\text { Means } \\
\pm \text { DP }\end{array}$ & $\begin{array}{c}\text { Means } \\
\pm D P\end{array}$ & $p$ & $\begin{array}{l}\text { Means } \\
\pm \mathrm{DP}\end{array}$ & $\begin{array}{l}\text { Means } \\
\pm \mathrm{DP}\end{array}$ & $\begin{array}{c}\text { Means } \\
\pm P\end{array}$ & $p$ \\
\hline Social function & $67.2 \pm 5.4$ & $61.1 \pm 11.1$ & $50.0 \pm 12.0$ & $0.371^{\mathrm{a}}$ & $65.5 \pm 10.6$ & $70.8 \pm 8.2$ & $58.9 \pm 6.2$ & $0.640^{\mathrm{a}}$ \\
\hline \multicolumn{9}{|l|}{ Symptoms scale } \\
\hline Fatigue & $40.8 \pm 5.0$ & $42.6 \pm 12.6$ & $71.3 \pm 9.4^{*}$ & $0.018^{a}$ & $37.3 \pm 9.3$ & $26.4 \pm 7.0$ & $58.9 \pm 5.5 \dagger$ & $\begin{array}{c}0.011 \\
\mathrm{a}\end{array}$ \\
\hline Nausea and vomit & $15.7 \pm 3.5$ & $5.6 \pm 3.5$ & $23.6 \pm 6.9$ & $0.212 b$ & $16.7 \pm 5.0$ & 0,0 & $20.6 \pm 4.1$ & $\underset{b}{0.561}$ \\
\hline Pain & $26.0 \pm 5.1$ & $11.1 \pm 7.0$ & $56.9 \pm 12.9 * \dagger$ & $0.036^{\mathrm{a}}$ & $19.0 \pm 7.6$ & $25.0 \pm 8.9$ & $38.9 \pm 7.1$ & $\begin{array}{c}0.192 \\
\mathrm{a}\end{array}$ \\
\hline \multicolumn{9}{|l|}{ Symptoms of items } \\
\hline Dyspnea & $13.7 \pm 4.5$ & $16.7 \pm 16.7$ & $22.2 \pm 11.1$ & $0.782^{\mathrm{a}}$ & $7.1 \pm 5.2$ & $8.3 \pm 5.5$ & $22.2 \pm 6.7$ & $0.346^{\mathrm{a}}$ \\
\hline Insomnia & $37.3 \pm 6.9$ & $16.7 \pm 11.4$ & $44.4 \pm 14.4$ & $0.249 b$ & $23.8 \pm 8.9$ & $12.5 \pm 12.5$ & $48.9 \pm 7.8^{*} \dagger$ & $0.032 \mathrm{c}$ \\
\hline Loss of appetite & $20.6 \pm 5.5$ & $5.6 \pm 5.6$ & $33.3 \pm 13.0$ & $0.256 \mathrm{~b}$ & $23.8 \pm 9.5$ & 0,0 & $26.7 \pm 6.7$ & $\begin{array}{c}0.593 \\
b\end{array}$ \\
\hline Constipation & $34.3 \pm 7.1$ & $33.3 \pm 21.0$ & $33.3 \pm 11.6$ & $0.997 \mathrm{~b}$ & $45.2 \pm 10.8$ & $29.2 \pm 16.0$ & $30.0 \pm 7.6$ & $0.346 \mathrm{~b}$ \\
\hline Diarrhea & $5.9 \pm 2.6$ & $33.3 \pm 21.0$ & $13.9 \pm 8.7$ & $0.347^{\mathrm{a}}$ & $16.7 \pm 8.4$ & $4.2 \pm 4.2$ & $10.0 \pm 4.8$ & $\begin{array}{c}0.546 \\
\mathrm{a}\end{array}$ \\
\hline \multicolumn{9}{|l|}{ Financial item } \\
\hline Financial difficulties & $31.4 \pm 6.4$ & $44.4 \pm 18.6$ & $58.3 \pm 12.4$ & $0.146^{\mathrm{a}}$ & $38.1 \pm 11.5$ & $50.0 \pm 12.6$ & $36.7 \pm 7.6$ & $0.413 a$ \\
\hline
\end{tabular}

Source: authors themselves.

Note: ap-value extracted from the Kruskal-Wallis test, with a difference between the means indicated by the Mann-Whitney test. bp-value extracted from the ANOVA test, with a difference between the means indicated by Tukey's Post Hoc test. cp-value extracted from the ANOVA test, with a difference between the means indicated by Duncan's Post Hoc test. * significant difference between the mean of 0 and $\geq 2$ dependent activities. $\dagger$ significant difference between the mean of 1 and $\geq 2$ dependent activities

Significance level adopted of $5 \%$.

\section{Discussion}

The results of the present study pointed to the existence of an association of paper performance with functional disability in ADL and IADL, of fatigue and pain with disability in ADL, and of insomnia with ADL. No strong correlations were found for quality of life and other indicators, only between paper performance and fatigue, and between social function and the presence of financial difficulties. When considering the scales and items of symptoms, fatigue and insomnia were the predominant symptoms, which, according to the literature, are considered to be related and to occur frequently in cancer patients, directly affecting the physical, psychological, and social spheres that often characterize barriers to functional recovery [19].

Regarding functional capacity, the ADL and IADL with greater degrees of dependence were dressing and bathing, and cleaning the house and washing clothes, respectively. This fact can be explained by the greater complexity and degree of demand these activities place on the physical and cognitive integrity of patients, when compared to other activities [20]. Based on this, it is possible to reinforce treatment recommendations that include complementary actions to traditional resources, in particular the performance of physical activity [21], besides identifying the need 
for further research in this area. In this way, with more evidence for this multidimensional, the identification of the main functional comorbidities and needs to be incorporated into treatment in this context can still be optimized. IADL are more complex to perform during the day, and therefore, they usually show higher levels of disability when compared to ADL [22]. However, in this study it was not possible to observe a wide disparity between them, because of the characteristics of the population, and possibly the level of fragility, resulting from the disease.

All correlations with the functions and symptoms of quality of life found in the present study were negative, with fatigue being linked to most of the functional scales, except for social function, which corroborates the findings of a synthesis of studies that assessed the quality of life of these patients and pointed out that most patients perceived deteriorated quality of life [23]. According to INCA [19], in addition to fatigue that interferes with daily life activities and patients' quality of life, fatigue is associated with other factors, such as lack of interest in routine and pleasurable activities (paper performance), loss or difficulty of concentration (cognitive function), and tendency to irritability (emotional function), among others.

Connected to fatigue are the symptoms of dyspnea and insomnia, which affect patients' functional capacity, as well as causing intense discomfort, feelings of distress, anxiety, fear, and worry [24]. Such factors may explain the significant correlation of both symptoms with the overall measure of health and quality of life, role performance, and emotional function in the present study. Additionally, the symptoms of nausea and vomiting, as well as loss of appetite, correlated significantly with the reduction in paper performance. This fact can be explained by the discomfort generated by possible changes in the palate during the treatment. Herzberg and Ferrari explain that patients start to eat less food than necessary, leading to weight loss and energy failure [25]. Thus, it is necessary to use reserves of fat and muscle, which, when intense and frequent, can cause dehydration, and electrolyte and nutrient imbalances, interfering with the disposition for routine activities [25].

The moderate negative correlation found between pain and function is evidenced by Herzberg and Ferrari [25], which suggests that living with cancer is not easy and usually has consequences that trigger feelings that can increase the degree of sensitivity to pain, forming a vicious cycle that affects the patient's quality of life. Finally, the financial difficulties item showed a moderate negative correlation with social function. Quality of life is affected, in these cases, because of concerns related to the remoteness of paid occupational activities [26]. Based on data from the present study, fatigue and dyspnea are symptoms that most influence quality of life in general and the overall health measure in this population.

In this study, when related the means of the scales and items of the EORTC-QLQ-C30 with functional disability for activities of daily living, compared the different degrees of dependence, it was noticed that more independent individuals presented better scores in general. For the ADL, significant differences between the means of none and two or more dependent activities were found for the role function, as well as for the fatigue and pain symptom scales. The decline in physical performance, fatigue, and pain are frequent problems in cancer patients and considerably interfere with their autonomy depending on the debilities caused [27] or mental health status [28].

For IADL, significant differences were found between the mean of none and a dependency activity for the paper performance functional scale and for the insomnia symptom item, while fatigue was only associated with dependence on two or more activities. Amorim, Silva, and Shimizu cited insomnia as one of the most frequent symptoms during oncological treatment, directly affecting the patient's daytime performance as well as their quality of life [29]; in addition, because they are related to various aspects of quality of life, the researchers considered regular programs of activity and physical exercise as an excellent non-pharmacological strategy to optimize treatment. It is interesting to note that the findings of this study speak to the proposal of the National Policy for Health Promotion, which aims to improve the health of the Brazilian population in its totality with the production of health and care measures, and, prior to this theme, prioritize actions of physical practices and physical activities [30].

The present study stands out for considering quality of life indicators of onco-hematologic patients under treatment as a primary outcome. Additionally, due to the fact that data collection was done only by one person and via interviews, there was a greater understanding of the participants for all the issues because of the readiness to clarify them whenever necessary. Finally, the questionnaire was constructed based on previously validated instruments, which made the measure of the indicators of interest more reliable. However, there were limitations in the cross-sectional design and sample 
size, which make it impossible to establish a more precise temporal relationship between the variables. In addition, the variability of the initial date of treatment, as well as the different stages of the disease and the particularity with which they act in each individual, are factors that affect the quality of life of patients and that probably influenced the results found. Furthermore, although the EORTC-QLQ-C30 is widely used in the oncology area and has high reliability, there is no instrument for the evaluation of exclusive symptoms of hematologic malignancies, more specifically of lymphoma and leukemia, and therefore, these could not be detected.

However, it is emphasized that there is no gold standard, and the EORTC-QLQ-C30 was chosen as the instrument for this study because of its validity, reproducibility, and reliability. Some of the symptoms commonly reported by patients with lymphoma that were not addressed in the questionnaire could have influenced the results, thus indicating a possible limitation of the study. Therefore, it is extremely important that more studies are carried out to clarify the correlation of these variables more accurately, so that alternatives capable of controlling the symptoms related to the disease and to the treatment may be found. With more precise results, actions or interventions can be developed and performed to improve the quality of life and multicomponent treatment of cancer patients.

\section{Conclusion}

Based on the results of the study, it was concluded that the association between lower scores on quality of life and functional disability reflects the damaging effects of hematologic neoplasms on the ability to perform basic and instrumental activities of daily living in individuals undergoing hospital treatment. Thus, it is necessary that preventive or control measures be applied in a complementary manner to oncological interventions, to direct points of action in non-drug therapies, to contribute to future health indicators in this population.

\section{References}

1. Instituto Nacional de Câncer (INCA). A situação do câncer no Brasil. Rio de Janeiro: Instituto Nacional de Câncer, Coordenação de Prevenção e Vigilância; 2006.

2. Lôbo SA, Fernandes AFC, de Almeida PC, de Lima Carvalho CM, Sawada NO. Qualidade de vida em mulheres com neoplasias de mama em quimioterapia. Acta Paul Enferm. 2014; 27(6):554-9.

3. Brasil. Ministério da Saúde. Instituto Nacional do Câncer. Estimativa 2016: Incidência de câncer no Brasil [Internet]. 2015[cited 2017 Jan 20];11.

4. Weber W. Esperança contra o câncer: a mente ajuda o corpo. Editora Europa; 2012.

5. Mello CNH, Martins MLC, Chamone D, Pinto KO, Santos NO, Luciant MCS. Intervenções psicológicas realizadas na clínica onco-hematolótica: discussão acerca das possibilidades clínicas apresentadas na literatura. Psicol Hosp. 2007;5(1):73-99.

6. Ferlay J, Soerjomataram I, Dikshit R, Eser S, Mathers C, Rebelo M, Parkin DM, Forman D, Bray F. Cancer incidence and mortality worldwide: Sources, methods and major patterns in GLOBOCAN 2012. Int J Cancer. 2015;136(5):E359-E386.

7. Búrigo T, Fagundes RL, Trindade E, Vasconcelos H, Massaut IH, Rotolo MAS. Ação do prebiótico sobre as proteínas de fase aguda de pacientes com neoplasia hematológica. Rev Bras Hematol Hemoter. 2007;29(2):130-135.

8. Frizzo MN, Silva FC, Araújo LS. Neoplasias hematológicas no idoso: uma revisão. Rev sal Int. 2016;(8)15-16.

9. Spinola AV, Manzzo I, Rocha C. As relações entre exercício físico e atividade física e o câncer. ConScientiae Saúde. 2007;6(1):39-48.

10. Lollar DJ, Crews JE. Redefining the role of public health in disability. Annu Rev Public Health. 2003;24(1):195-208. 
11. Battaglini CL, Bottaro M, Campbell JS, Novaes J, Simão R. Atividadefísica e níveis de fadiga em pacientes portadores de câncer. Rev Bras Med Esporte. 2004;10(2):98-104.

12. Macedo A, Andrade S, Moital I, Moreira A, Pimentel F, Barroso S, Dinis J, Afonso N, Bonfill X. Perfil da doença oncológica em Portugal: racional, objectivos e metodologia estudo perfil. Acta Med Port. 2008;21(4):329-334.

13. Nicolussi, AC. Relaxamento com imagem guiada: influência sobre a qualidade de vida relacionada à saúde de pacientes com câncer durante o tratamento quimioterápico. Tese. São Paulo: Universidade de São Paulo; 2012.

14. Allart P, Soubeyran P, Cousson-Gélie F. Are psychosocial factors associated with quality of life in patients with haematological cancer? A critical review of the literature. Psychooncology. 2013;22(2):241-249.

15. Ribeiro JLP, Pinto C, Santos C. Validation study of the Portuguese version of the QLC-C30-V. 3. Psic, Saúde \& Doenças. 2008;9(1):89-102.

16. Katz S, Ford AB, Moskowitz RW, Jackson BA, Jaffe MW. Studies of illness in the aged: the index of ADL: a standardized measure of biological and psychosocial function. Jama. 1963;185(12):914-919.

17. Lawton MP, Brody EM. Assessment of older people: selfmaintaining and instrumental activities of daily living. Nursing Research. 1970;19(3):278.

18. Franzblau AN. A primer of statistics for non-statisticians. Oxford: Harcourt, Brace; 1958.

19. Instituto Nacional de Câncer (INCA). Ações de enfermagem para o controle do câncer: uma proposta de integração ensino-serviço. Rio de Janeiro: INCA; 2008.

20. Barbosa BR, de Almeida JM, Barbosa MR, Rossi-Barbosa LAR. Avaliação da capacidade funcional dos idosos e fatores associados à incapacidade. Ciênc Saúde Coletiva [online]. 2014;19(8)

21. World Health Organization (WHO). World Health Organization. Management of Substance Abuse Unit. Global status report on alcohol and health, 2014. World Health Organization; 2014.

22. Nunes JD, Saes MO, Nunes BP, Siqueira FCV, Soares DC, Fassa MEG, Thumé E, Facchini LA. Indicadores de incapacidade funcional e fatores associados em idosos: estudo de base populacional em Bagé, Rio Grande do Sul. Epidemiol Serv Saúde. 2017;26(2):295-304.
23. Allart-Vorelli P, Porro B, Baguet F, Michel, A, Cousson-Gélie F. Haematological cancer and quality of life: a systematic literature review. Blood Cancer J. 2015;5(4):305.

24. Vendrusculo, LM. Capacidade Funcional e Qualidade de Vida de mulheres com câncer de mama após o tratamento oncológico. Tese. São Paulo: Universidade de São Paulo; 2011.

25. Herzberg V, Ferrari CLS. Tenho câncer e agora. São Paulo: Ed Assoc Bras Câncer; 2006.

26. Calefi KAC, Rocha V, Nabhan SK, Maftum MA, Kalinke LP, Mantovani MF. Qualidade de vida do paciente com neoplasia hematológica submetido à quimioterapia. REME - Rev Min Enferm. 2014;18(1):41-47.

27. Mota D, Pimenta C. Fadiga em doentes com câncer colo-retal: fatores de risco e preditivos. Esc Enferm Universidade São Paulo; 2008.

28. Kroenke K, Theobald D, Wu J, Loza JK, Carpenter JS, $\mathrm{Tu}$ W. The association of depression and pain with health-related quality of life, disability, and health care use in cancer patients. J Pain Symptom Manage. 2010;40(3):327-341.

29. Amorim JR, Silva IA, Shimizu IS. Avaliação da qualidade de sono em pacientes com câncer de mama em quimioterapia. Rev Bras Mastologia. 2017;27(1).

30. Brasil. Ministério da Saúde. Secretaria de Vigilância em Saúde. Secretaria de Atenção à Saúde. Política Nacional de Promoção da Saúde: PNPS: revisão da Portaria MS/ GM nº 687, de 30 de março de 2006/ Ministério da Saúde, Secretaria de Vigilância em Saúde, Secretaria de Atenção à Saúde. Brasília: Ministério da Saúde; 2015.

Received in 18/08/2017

Recebido em 18/08/2017

Recibido en 18/08/2017

Approved in 24/05/2018 Aprovado em 24/05/2018 Aprobado en 24/05/2018 


\title{
Erratum
}

In the article "Quality of life and functional capacity during the treatment of hematologic neoplasms", DOI number: http://dx.doi.org/10.1590/1980-5918.031.A037, published in Revista Fisioterapia em Movimento, v. 31, e003137, 2018, (http://www.scielo.br/pdf/fm/v31/1980-5918-fm-31-e003137.pdf), on page 5:

Where it reads:

Figure 1. Degree of dependence (\%) for the basic and instrumental forms of life in patients with hematologic neoplasms in cancer treatment. Florianopolis, 2016.

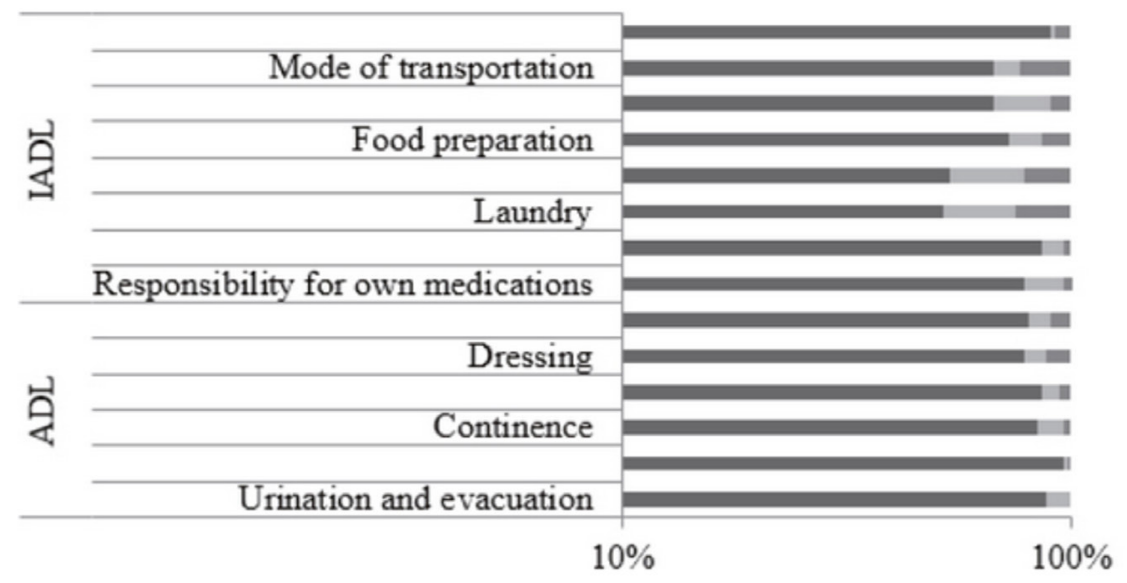

\author{
Independents \\ = Partially \\ dependent
}

It should read: 
Figure 1. Degree of dependence (\%) for the basic and instrumental forms of life in patients with hematologic neoplasms in cancer treatment. Florianopolis, 2016.

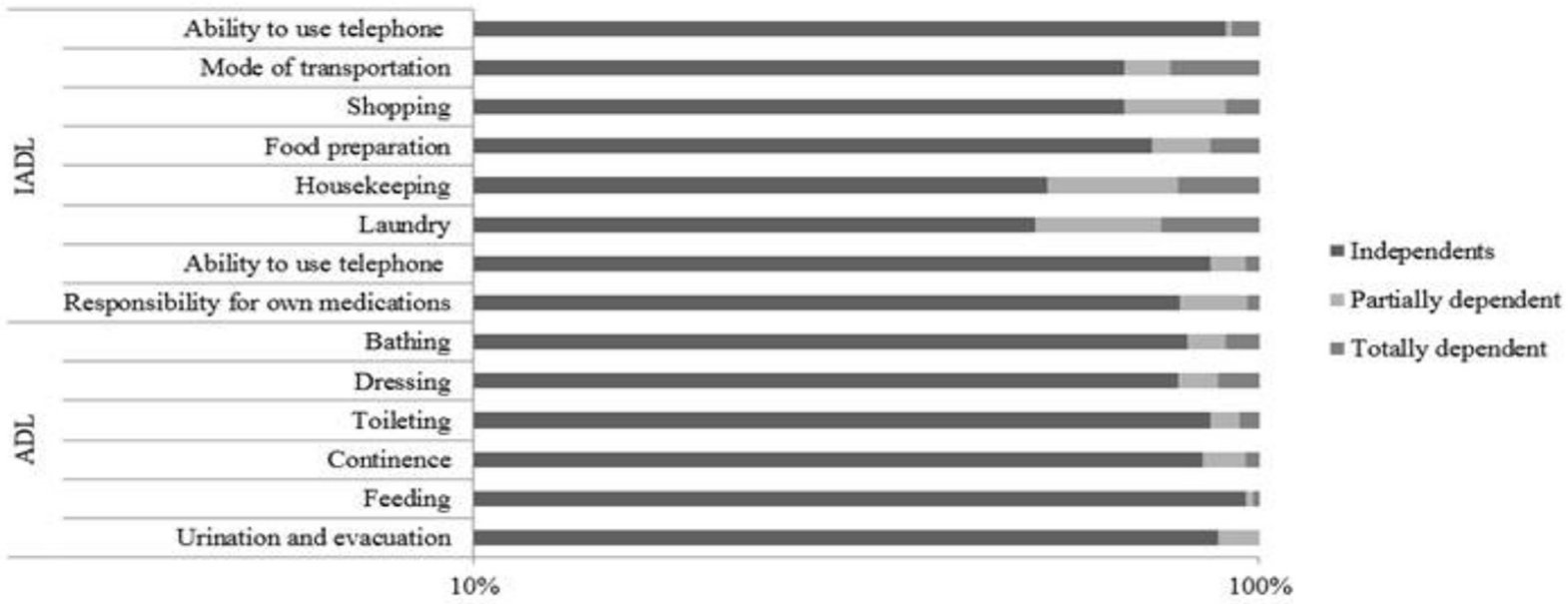

